Bulletin of Pharmaceutical Sciences
Assiut University
Website: http://bpsa.journals.ekb.eg/
e-mail: bullpharm@aun.edu.eg

\title{
VIRULENCE DETERMINANTS OF ESCHERICHIA COLI STRAINS ISOLATED FROM SURGICAL SITE INFECTIONS AT SELECTED HOSPITALS IN SYRIA
}

\author{
N. Daoud ${ }^{1,2^{*}}$, A. Abou Sulaiman ${ }^{3}$ and K. H. Al Kwatli ${ }^{1}$ \\ ${ }^{1}$ Department of Biochemistry and Microbiology, Faculty of Pharmacy, Damascus University, \\ Syria \\ ${ }^{2}$ Department of Life Science, Faculty of Dentistry, Damascus University, Syria \\ ${ }^{3}$ Department of Periodontology, Faculty of Dentistry, Damascus University, Syria
}

\begin{abstract}
Escherichia coli is one of the most commonly isolated pathogens from surgical site infections (SSIs) that accounts for significant morbidity and mortality, especially with high virulent strains. The purpose of this study was to evaluate the virulence determinants of E. coli strains isolated from surgical sections. 51 E. coli isolates were assessed for biofilm formation, mannose-sensitive or -resistant hemagglutination, capsule, hemolysin and siderophores production. Antibiotic susceptibility against 14 common antibiotics was performed. As a result, 25 strains displayed 5 virulence factors and multiple drug resistance towards more than 11 antibiotics. DNA and plasmids were extracted from the 25 virulent isolates. PCR was used to investigate virulence genes on DNA encoding adhesins (fimH-1, mrkD), hemolysin (hlyA), siderophores (entB: enterobactin, iutA: aerobactin, irp-1: yersiniabactin- which was encoded on (HPI) high-pathogenicity island). MrkD, iutA and hlyA genes were also screened on extracted plasmids. The most common virulence genes were iutA (25/100\%), mrkD (24/96\%), entB $(23 / 92 \%)$ and fimH-1 (21/84\%). Irpl was found at moderate rates $(15 / 60 \%)$ and at lower prevalence, was gene hlyA (2/8\%). Plasmids were found in 16/25 strains. MrkD and iutA were present in $10 / 16$ plasmids, whereas none of them harbored hlyA. In conclusion, most E. coli isolates harbored high frequencies of (fimH1, mrkD, entB and iutA) which seem to be at the basis of pathogenicity. However, some strains, which carry HPI and have virulence plasmids can account for even more real threat if they spread among other Enterobacteriaceae members in surgical sections.
\end{abstract}

\section{INTRODUCTION}

Surgical site infections (SSIs) are one of the most common types of nosocomial infections and major global health problem ${ }^{1 \& 2}$. SSIs can lead to increasing the patients' health care cost and hospital stay, morbidity, and mortality ${ }^{2 \& 3}$.

These infections are usually caused by microorganisms, especially gram positive and gram negative bacteria that may enter the patient's wound during or after the surgery ${ }^{3}$. One of the most commonly isolated gram negative bacteria according to bacteriological studies is Escherichia coli ${ }^{4}$.
E. coli is a facultative anaerobic bacterium belonging to the Enterobacteriaceae ${ }^{5}$. Some $E$. coli strains may cause intestinal and extraintestinal infections in humans. The strains that cause gastroenteritis are commonly referred to as the diarrheagenic and are subdivided into six pathotypes, i.e. enterotoxigenic E. coli (ETEC), enteropathogenic $E$. coli (EPEC), enterohemorrhagic E. coli (EHEC), enteroaggregative E. coli (EAEC), enteroinvasive E. coli (EIEC), and diffusely adhering E. coli (DAEC) ${ }^{6 \& 7}$. Whereas extraintestinal pathogenic $E$. coli (ExPEC) group includes uropathogenic E. coli (UPEC), neonatal meningitis E. coli (NMEC),

Received in 9/9/2020 \& Accepted in 2/10/2020 
sepsis-associated E. coli (SEPEC), and avian pathogenic E. coli (APEC) ${ }^{8}$.

E.coli strains' Pathogenicity is related to the virulence factors that it has, such as: adhesins, toxins, siderophores, lipopolysaccharides, capsules, and invasins ${ }^{8 \& 9}$. A combination of factors will make the bacterium more virulent and cause more infections ${ }^{10}$.

The acquisition of virulence genes which encode to virulence factors is believed to increase the pathogenicity of bacteria and the severity of infection with the great possibility of therapy failure ${ }^{11}$.

These virulence factors are encoded on pathogenicity islands (PAIs) and plasmids ${ }^{8}$. These plasmids can be either integrated into the chromosome or replicate independently as extrachromosomal elements and later on they can be transferred to other species contributing to inter- intra-species variability in genomic contents ${ }^{10}$.

Surface virulence factors (adhesins) such as type 1, type 3 fimbriae (which are encoded by fim $H$ and $m r k D$ genes respectively) are very important as the main attachment factor ${ }^{6} . \alpha$ haemolysin $(h l y A)$ is an important lipoprotein toxin that constitutes a part from adhesins ${ }^{6}$. Other important virulence factors are siderophores, low-molecular-weight compounds possessing a high affinity for iron, which are necessary for the growth of bacteria ${ }^{12}$. Some strains of $E$. coli have several types of siderophores including: A catechol-type siderophore (Enterobactin), a hydroxamatetype siderophore (Aerobactin) and a mixedtype siderophore (yersiniabactin) ${ }^{13}$.

Therefore, the present study was proposed to detect virulence factors and genes of $E$. coli strains isolated from surgical site infections and to evaluate the concomitant presence of plasmids that could be transferred to other species.

\section{MATERIALS AND METHODS}

\section{Patients, samples and identification of isolates}

The study comprised (51) strains of E. coli isolated from surgical site infections in patients (one isolate per patient) attending different surgery sections at 5 Academic hospitals in Damascus University.
Samples were collected from 27 females and 24 males aged between 20-60 years with an average age of $40 \pm 5$ years.

Samples were allocated into the following surgery sections: Maxillofacial and Periodontal Surgery $(n=14)$, Urological $(n=9)$, Gastrointestinal $(n=8)$, Pulmonology $(n=6)$, Orthopedic Surgery $(n=5)$, Gynecology $(n=5)$ and Heart Surgery $(n=4)$. The study was conducted during the period of (May 2018 April 2019).

Identification of $E$. coli strains was done by biochemical tests (API20E, Biomerieux).

\section{Phenotypic detection of virulence properties of $E$. coli strains}

- Determination of 6 virulence factors was performed as follows:

- Biofilm formation (BF) was tested by microtiter plate assay procedure ${ }^{14}$.

- Hemagglutination assays for Mannosesensitive hemagglutination (MSHA) specific for type 1 fimbriae and Mannoseresistant hemagglutination (MRHA) specific for type 3 fimbriae; the procedure was done according to the protocol described by M. Mishra et al. (2001) ${ }^{15}$.

- Hemolysin production (Hly-A) was detected as a clear zone of lysis on blood $\operatorname{agar}^{16}$.

- Capsule detection (CPS) by staining with India ink ${ }^{17}$.

- Siderophores production assays were detected by the chrome azurol S (CAS) assay $^{18}$.

\section{- Antibiotic susceptibility testing}

Antibiotic susceptibility was determined by the Kirby-Bauer disk diffusion method on Mueller-Hinton agar. The zones of inhibition were interpreted using the CLSI criteria (CLSI, 2018) ${ }^{19}$. The following Antibiotics were tested: Amoxicillin, Cefotaxime, Ceftriaxone, Cefepime, Nitrofurantoin, Doxycycline, Amoxicillin-Clavulanate, SulfamethoxazoleTrimethoprim, Ciprofloxacin, Levofloxacin, Amikacin, Gentamicin, Imipenem and Colistin.

\section{DNA and plasmids extraction}

25 of 51 strains had 5 virulence factors (BF, MSHA, MRHA, CPS, Siderophores).

Extraction of DNA and plasmids of these

25 virulent strains was done utilizing 
commercially available bacterial genomic DNA Purification kit and Plasmid Purification kit (Intron, Korea). Concentration of extracted genomic DNA and plasmids was measured by Nano drop system (Thermo, USA). DNA and plasmids were stored at $\left(-20^{\circ} \mathrm{C}\right)$.

\section{PCR detection of virulence genes}

PCR was conducted using specific primers to detect genes encoding type 1 and type 3 adhesins (fimH-1, $m r k D)$, enterobactin biosynthesis (entB), aerobactin receptor (iutA), yersiniabactin biosynthesis (irp-1), Hemolysin a $(h l y A)$.

MrkD, iutA and $h l y A$ genes were detected on DNA and plasmids because they could be encoded on both, whereas fimH-1, entB and irp- 1 genes were only detected on DNA.

Table 1 demonstrates the Characteristics of the applied PCR protocol.

PCR conditions were: $94^{\circ} \mathrm{C}$ for $4 \mathrm{~min}$., followed by 30 cycles of $94^{\circ} \mathrm{C}$ for $30 \mathrm{sec}$, annealing temperature for $40 \mathrm{sec}, 72^{\circ} \mathrm{C}$ for 1 min, and $72{ }^{\circ} \mathrm{C}$ for 10 min. ${ }^{16}$.

The electrophoresis of PCR products was performed on $1.5 \%$ agarose gels with a proper DNA ladder (Fig. 1). $(5 \mu \mathrm{l})$ of Ethidium bromide was added to the gel to be visualized with UV system (Cleaver Scientific, UK).

\section{RESULTS AND DISCUSSION}

\section{Results}

Analysis of virulence factors and antimicrobial resistance

This study was carried out to identify virulence properties of (51) E. coli strains isolated from SSIs. The prevalence of studied virulence factors is shown in figure (2-a). It was observed that $(25 / 51)$ strains had 5 virulence factors (BF, MRHA, MSHA, CPS, siderophores).

The distribution of virulence factors among (51) E. coli clinical isolates collected from different surgical site infections is shown in figure 3. It was observed that 25 strains showed high virulence ( 5 virulence factors), 18 showed moderate virulence (3-4 virulence factors) and only 8 were low virulent (1-2 virulence factors).

The evaluation of the susceptibility of the 51 isolates to 14 common antibiotics showed high resistance especially for $\beta$-lactam and cephalosporins. The lowest resistance was to colistin, Imipenem and aminoglycosides, (Table 2). Multi drug resistance (MDR) revealed that all isolates were resistant to more than 8 antibiotics and 2 were resistance to all used antibiotics. The 25 strains which had 5 virulence factors showed resistance to more than 11 antibiotics.

Table 1: Primers, annealing temperature and expected size used in study.

\begin{tabular}{|l|l|c|c||}
\hline Gene name & \multicolumn{1}{|c|}{ Primer sequence $\left(5^{\prime}-3^{\prime}\right)$} & \multicolumn{1}{|c||}{$\begin{array}{c}\text { Annealing } \\
\text { temperature }\left({ }^{\circ} \mathrm{C}\right)\end{array}$} & $\begin{array}{c}\text { Expected size } \\
\text { (bp) } \\
\text { (Amplicon) }\end{array}$ \\
\hline fimH-1 $^{20}$ & $\begin{array}{l}\text { F: ATGAACGCCTGGTCCTTTG } \\
\text { R: GCTGAACGCCTATCCCCTGC }\end{array}$ & 55 & 688 \\
\hline mrkD $^{16}$ & $\begin{array}{l}\text { F: CCACCAACTATTCCCTCGAA } \\
\text { R: ATGGAACCCACATCGACATT }\end{array}$ & 52 & 240 \\
\hline entB $^{16}$ & $\begin{array}{l}\text { F: ATTTCCTCAACTTCTGGGGC } \\
\text { R: AGCATCGGTGGCGGTGGTCA }\end{array}$ & 57 & 371 \\
\hline iutA $^{21}$ & $\begin{array}{l}\text { F: GGCTGGACATCATGGGAACTGG } \\
\text { R: CGTCGGGAACGGGTAGAATCG }\end{array}$ & 63 & 300 \\
\hline irp-1 $^{22}$ & $\begin{array}{l}\text { F: TGAATCGCGGGTGTCTTATGC } \\
\text { R: TCCCTCAATAAAGCCCACGCT }\end{array}$ & 57 & 238 \\
\hline hlyA $^{21}$ & $\begin{array}{l}\text { F: AACAAGGATAAGCACTGTTCTGGCT } \\
\text { R: ACCATATAAGCGGTCATTCCC }\end{array}$ & 63 & 1177 \\
\hline
\end{tabular}

fim H-1: fimbriae of type 1, mrkD: fimbriae of type 3, entB: enterobactin biosynthesis, iutA: aerobactin receptor, irp-1: yersiniabactin biosynthesis, hlyA: Hemolysin. 


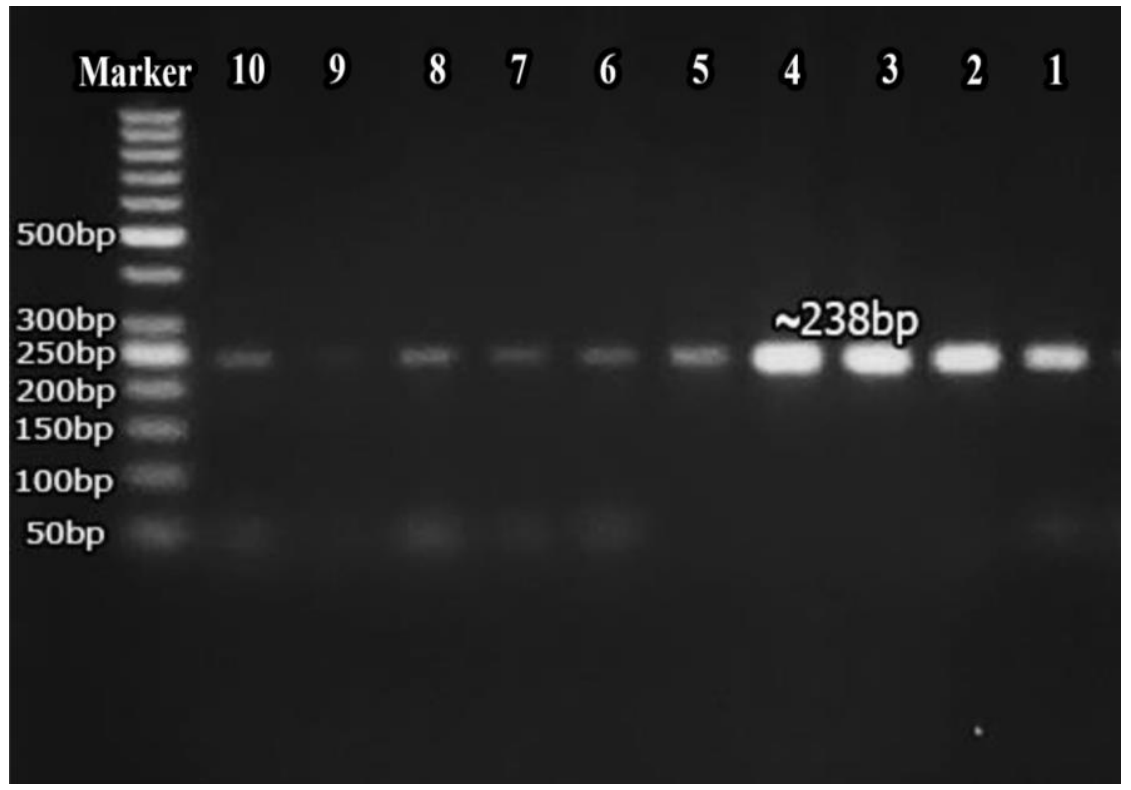

Fig. 1: Agarose gel electrophoresis showing amplification products of the irpl gene. Lines 1-10: representative the results of amplified product (238bp) of E. coli isolates.

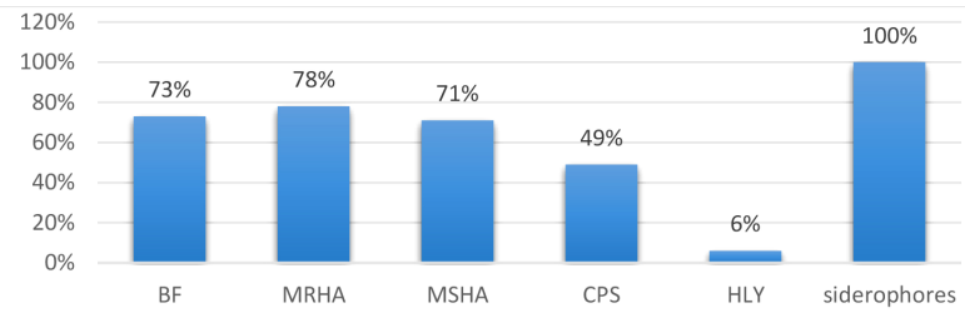

Fig (2-a) Prevalence of virulence factors of (51) E.coli strains

BF: Biofilm formation, MSHA: Mannose-sensitive hemagglutination, MRHA: mannose-resistan hemagglutination, CPS: Capsule, HLY-A: Hemolysin

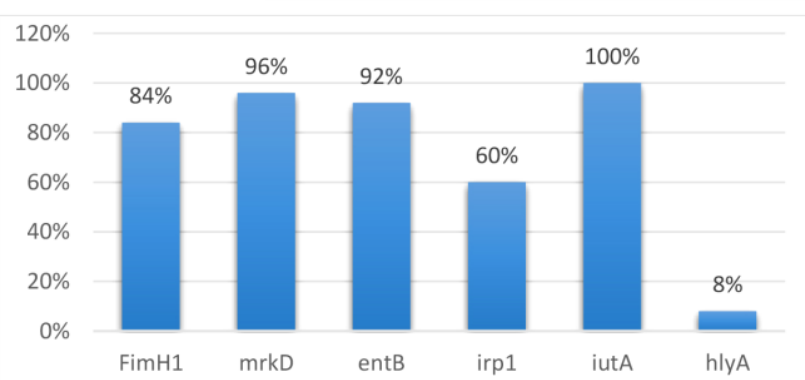

Fig (2-b) Prevalence of virulence genes on DNA of (25) E.coli strains

fim $\mathrm{H}-1$ : fimbriae of type 1, mrkD: fimbriae of type 3, entB: enterobactin biosynthesis, iutA: aerobactin receptor, irp-1: yersiniabactin biosynthesis, hlyA: Hemolysin

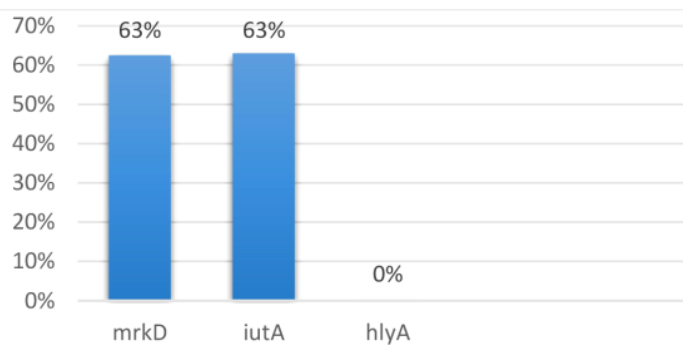

Fig (2-c) Prevalence of virulence genes on plasmids of (16) E.coli strains

mrkD: fimbriae of type 3, iutA: aerobactin receptor, hlyA: Hemolysin

Fig. 2: Prevalence of virulence factors and genes of $E$. coli strains. 
Table 2: Antibiotic resistance pattern of (51) E. coli strains and antibiogram profiles of MDR (multi drug resistance strains).

\begin{tabular}{|c|c|c|c|c|}
\hline \multicolumn{2}{|r|}{ Antibiotic tested } & $\begin{array}{c}\text { Resistant } \\
\text { strains } \\
\text { Number }-(\%)\end{array}$ & MDR & $\begin{array}{c}\text { Number } \\
(\%)\end{array}$ \\
\hline 1 & Amoxicillin & $51(100 \%)$ & \multirow{2}{*}{ Resistance to 8 antibiotics } & 7 \\
\hline 2 & Cefotaxime & $51(100 \%)$ & & $(13.7 \%)$ \\
\hline 3 & Ceftriaxone & $51(100 \%)$ & \multirow{2}{*}{ Resistance to 9 antibiotics } & \\
\hline 4 & Cefepime & $49(96 \%)$ & & $(19.6 \%)$ \\
\hline 5 & Nitrofurantoin & $47(92.1 \%)$ & \multirow{2}{*}{ Resistance to 10 antibiotics } & \\
\hline 6 & Doxycycline & $43(84.3 \%)$ & & $(17.6 \%)$ \\
\hline 7 & Amoxicillin-Clavulanate & $41(80.4 \%)$ & \multirow{2}{*}{ Resistance to 11 antibiotics } & \\
\hline 8 & Sulfamethoxazole-Trimethoprim & $38(74.5 \%)$ & & $(17.6 \%)$ \\
\hline 9 & Ciprofloxacin & $35(68.6 \%)$ & \multirow{2}{*}{ Resistance to 12 antibiotics } & 4 \\
\hline 10 & Levofloxacin & $33(64.75 \%)$ & & $(7.8 \%)$ \\
\hline 11 & Gentamicin & $30(58.5 \%)$ & \multirow{2}{*}{ Resistance to 13 antibiotics } & 10 \\
\hline 12 & Amikacin & $28(54.9 \%)$ & & $(19.6 \%)$ \\
\hline 13 & Imipenem & $28(54.9 \%)$ & \multirow{2}{*}{ Resistance to 14 antibiotics } & 2 \\
\hline 14 & Colistin & $23(45.1 \%)$ & & $(3.9 \%)$ \\
\hline
\end{tabular}

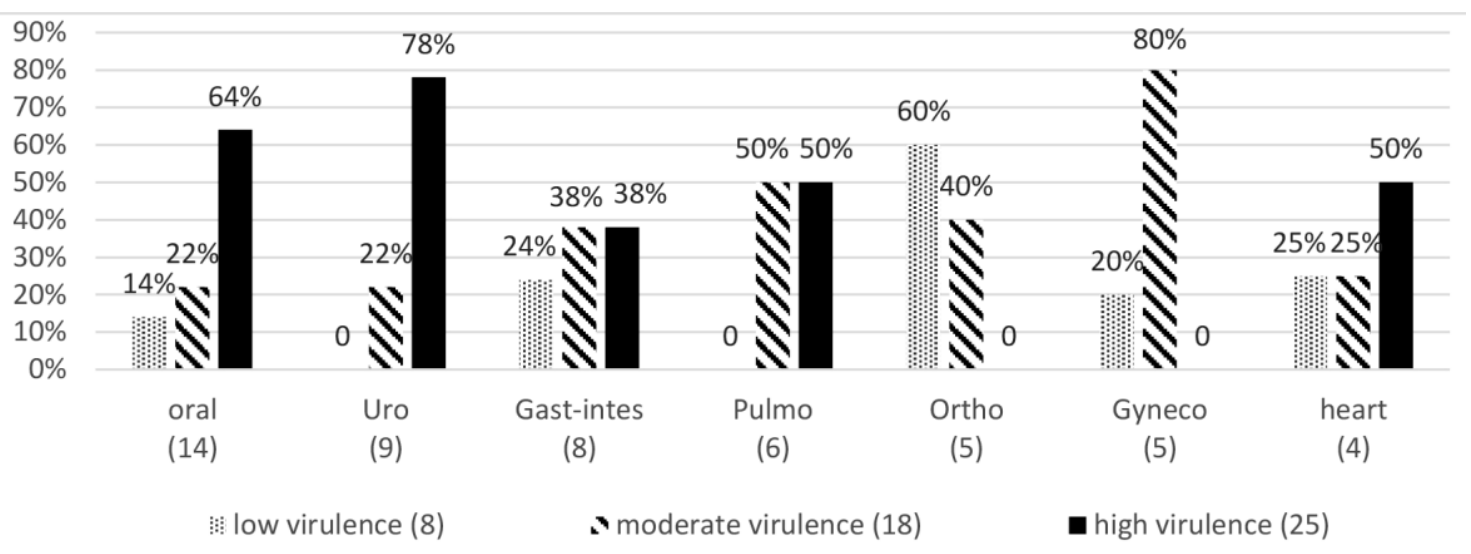

Fig. 3: Distribution of virulence factors of (51) E. coli strains according to the surgical site sections.

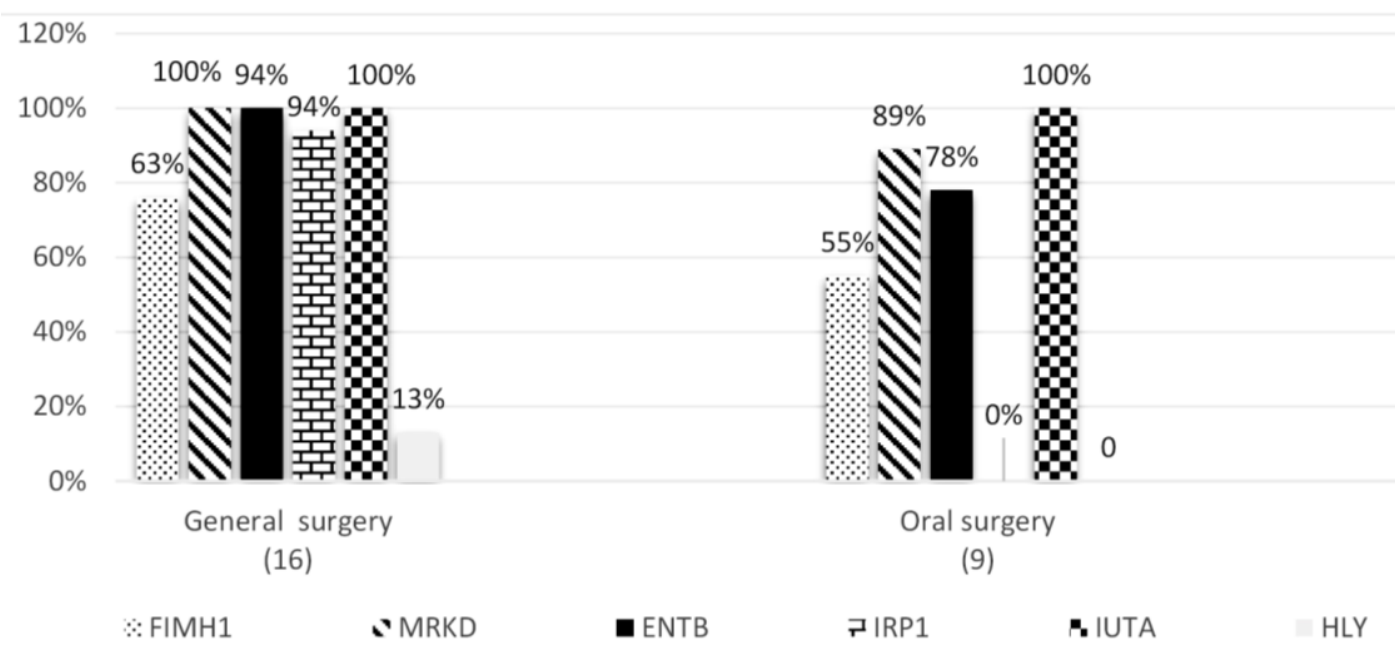

Fig. 4: Distribution of DNA virulence genes of (51) E. coli strains according to the surgical site sections. 


\section{Genes study}

Extraction protocol of DNA and plasmids involved on (25) strains revealed that plasmids were only found in 16 strains (64\%).

Figure (2-b) shows the prevalence of the virulence genes that were detected on DNA. fim $H-1$ and $m r k D$ genes, encoding type 1 and type 3 fimbrial adhesins, were present in $84 \%$ and $96 \%$ of isolates respectively. Siderophore genes entB (enterobactin), iutA (aerobactin), irpl (yersiniabactin) were detected at the prevalences of $92 \%, 100 \%$ and $60 \%$, respectively. Hemolysin A gene (hlyA) was only found in 2 strains.

On the other hand, mrkD, iutA and hlyA genes were also present on the sixteen extracted plasmids (Fig. 2-c). mrkd and iutA were found in $62.5 \%$ of plasmids whereas none of them harbored hlyA.

The distribution of virulence genes among (25) virulent E. coli isolates collected from different surgical site infections is shown in (Fig. 4). It was noted that the virulence genes were detected in almost all E. coli strains isolated from General surgery except hlyA which was found only in 2 urological strains, whilst the oral isolates did not show irpl or hlyA genes.

\section{Discussion}

E. coli is considered one of the leading worldwide causes of SSIs. In Syria, the pathogenicity and virulence properties of $E$. coli in general and especially those isolated from SSIs are not studied enough. In this study we screened $E$. coli strains for determination of virulence factors, genes and plasmids at selected hospitals in Syria.

Among 51 isolates, more than $70 \%$ of them displayed BF, MRHA and MSHA. This may be related to fimbriae role in the first essential step in formation and development of biofilm-associated infections that could shield the bacteria from opsonization and phagocytosis $^{23}$. Additionally, siderophores was detected in all strains because $E$. coli is an extracellular pathogen and hence did not has readily access to iron so it produces siderophores to uptake iron from the body. Also, about half of our strains had polysaccharide capsules making them more virulent.
One interesting finding of the present study was that the 25 high virulent strains displayed MDR towards more than 11 antibiotics and 2 against all tested antibiotics. This finding can be attributed to the fact that the hospitalized patients had excessive treatments with antibiotics during their stay in the hospital. The resistance to colistin and Imipenem were lower than other antibiotics due to not being used infrequently and randomly in Syria.

The genes fimH-1 and mrkD were found in a high percentage of our isolates. This result is consistent with the role of type 1 fimbriae as the major factor responsible for the enhanced adhesive and invasive properties of $E$. coli ${ }^{8}$, and type 3 fimbriae which allow adhesion to various human tissue structures and are potent promoter of biofilm formation on biotic surfaces ${ }^{23}$.

According to data from this study entB gene was detected in $23 / 25$ isolates. This finding is in line with previous studies which showed that enterobactin is found in most $E$. coli strains, both commensal and pathogenic ${ }^{8}$, Nonetheless, another study pointed to enterobactin's role in the promotion of biofilm development and maturation ${ }^{24}$.

One remarkable finding of this study was that the iutA gene was present in all isolates, This result suggests the high virulence of the tested strains due to the fact that other studies have reported that the commensal strains do not show this gene ${ }^{25}$, and the aerobactin receptor shows much greater efficiency in capturing $\mathrm{Fe}$ than enterobactin ${ }^{8}$. Paauw et al. has also demonstrated that aerobactin cause indirectly reduced killing capacity of innate immune cells $^{26}$.

The irpl gene was found in $15 / 25$ of isolates, thus indicating that each of these 15 strains carries a high-pathogenicity island (HPI) which irpl gene is encoded on. This result is important in pathogenicity evaluation because (HPI) presence is essential for the expression of a high-virulence phenotype. In addition, it can be considered as an ironcapture island that could spread among various members of the Enterobacteriaceae family by horizontal transfer as suggested by Bach et al. $^{27}$.

Another notable finding of this study was that the hlyA gene was only present in 2 
isolates which were isolated from urology section, this is consistent with other studies that reported that uropathogenic $E$. coli (UPEC) isolates encode $h l y A$ at high proportion ${ }^{28}$.

Plasmids were found in 16/25 strains. Furthermore, 10 of these16 were virulence plasmids because they possess virulence genes (iutA, mrkD). These plasmids could be transferred to other species contributing to the spread of the aforementioned virulence genes among bacterial populations ${ }^{29}$.

\section{Conclusion}

This study exhibits a high occurrence frequency of some virulence factors (biofilm formation, fimbriae type 1,3 and siderophores) among $E$. coli strains isolated from SSIs. Moreover, E. coli isolates harbor a high frequency of some virulence genes encoded on genomic DNA (fimH1, mrkD, entB and iutA), In contrast irpl (encoded on high pathogenicity islands), $m r k D$ and $i u t A$ (encoded on virulence plasmids) were detected only in some isolates.

Finally, it could be further presumed that these isolates constitute a genuine threat to the vulnerable populations. Hence, control measures need to be enhanced to prevent these isolates from spreading among Enterobacteriaceae members especially in surgical sections.

\section{Acknowledgements}

The authors are grateful to Damascus University for funding this research.

\section{Conflict of interest}

The Authors declare that this study has no conflict of interest.

\section{Ethical approval}

The study was approved by the Institutional Review Board of Damascus University.

\section{REFERENCES}

1- H. A. Khan, F. K. Baig and R. Mehboob, "Nosocomial infections: Epidemiology, prevention, control and surveillance", Asian Pacific Journal of Tropical Biomedicine, 7 (5), 478-82 (2017).

2- W. Dessie, G. Mulugeta, S. Fentaw, A. Mihret, M. Hassen and E. Abebe, "Pattern of bacterial pathogens and their susceptibility isolated from surgical site infections at selected referral hospitals, Addis Ababa, Ethiopia", International Journal of Microbiology, 2016, Article ID 2418902, 1-8 (2016).

3- V. Negi, S. Pal, D. Juyal, M. K. Sharma and N. Sharma, "Bacteriological profile of surgical site infections and their antibiogram: A study from resource constrained rural setting of Uttarakhand state, India", Journal of Clinical and Diagnostic Research: JCDR., 9 (10), DC17, (2015).

4- C. Owens and K. Stoessel, "Surgical site infections: Epidemiology, microbiology and prevention", Journal of Hospital Infection, 70, 3-10 (2008).

5- D. A. Pereira, M. C. Vidotto, K. A. Nascimento, A. C. Rd. Santos, M. L. Mechler and L. Gd. Oliveira, "Virulence factors of Escherichia coli in relation to the importance of vaccination in pigs", Ciência Rural., 46 (8), 1430-7 (2016).

6- R. M. Khairy, E. S. Mohamed, H. M. Abdel Ghany and S. S. Abdelrahim, "Phylogenic classification and virulence genes profiles of uropathogenic E. coli and diarrhegenic E. coli strains isolated from community acquired infections", PLoS ONE, 14 (9), e0222441 (2019).

7- L. Cabrera-Sosa and T. J. Ochoa, "Escherichia coli Diarrhea. Hunter's Tropical Medicine and Emerging Infectious Diseases", Eds: Edward T. Ryan, David R. Hill, Tom Solomon, Naomi E. Aronson and Timothy P. Endy, Elsevier, $10^{\text {th }}$ Edn., 2020, pp. 481-5.

8- J. Sarowska, B. Futoma-Koloch, A. JamaKmiecik, M. Frej-Madrzak, M. Ksiazczyk, G. Bugla-Ploskonska, et al., "Virulence factors, prevalence and potential transmission of extraintestinal pathogenic Escherichia coli isolated from different sources: recent reports", Gut Pathogens, 11 (1), 10 (2019).

9- E. Bok, A. Kożańska, J. MazurekPopczyk, M. Wojciech and K. BaldyChudzik, "Extended phylogeny and extraintestinal virulence potential of commensal Escherichia coli from piglets and sows", International Journal of Environmental Research and Public Health, 17 (1), 366 (2020). 
10- J. Pitout, "Extraintestinal pathogenic Escherichia coli: A combination of virulence with antibiotic resistance", Frontiers in Microbiology, 3, 9 (2012).

11- R. M. Abd El-Baky, R. A. Ibrahim, D. S. Mohamed, E. F. Ahmed and Z. S. Hashem, "Prevalence of virulence genes and their association with antimicrobial resistance among pathogenic $E$. coli isolated from Egyptian patients with different clinical infections", Infection and Drug Resistance, 13, 1221 (2020).

12- R. C. Hider and X. Kong, "Chemistry and biology of siderophores", Natural Product Reports, 27 (5), 637-57 (2010).

13- S. Sah and R. Singh, "Siderophore: Structural and functional characterisationA comprehensive review", Agriculture (Pol'nohospodárstvo), $61 \quad$ (3), 97-114 (2015).

14- N. Maldonado, C. Silva de Ruiz, M. Cecilia and M. Nader-Macias, "A Simple Technique to Detect Klebsiella BiofilmForming-Strains. Inhibitory Potential of Lactobacillus fermentum CRL 1058 Whole Cells and Products", In: Communicating Current Research and Educational Topics and Trends in Applied Microbiology, ed. Méndez Vilas A. (Spain: FORMATEX), 2007, pp. 52-9.

15- M. Mishra, Y. Thakar and A. Pathak, "Haemagglutination, haemolysin production and serum resistance of Proteus and related species isolated from clinical sources", Indian Journal of Medical Microbiology, 19 (2), 5 (2001).

16- R. El Fertas-Aissani, Y. Messai, S. Alouache and R. Bakour, "Virulence profiles and antibiotic susceptibility patterns of Klebsiella pneumoniae strains isolated from different clinical specimens", Pathologie-Biologie, 61 (5), 209-16 (2013).

17- D. P. Breakwell, R. B. Moyes and J. Reynolds, "Differential staining of bacteria: Capsule stain", Current Protocols in Microbiology, 15 (1), A. 3I, 1-A. 3I. 4 (2009).

18- B. Schwyn and J. Neilands, "Universal chemical assay for the detection and determination of siderophores", Analytical Biochemistry, 160 (1), 47-56 (1987).
19- A. Wayne, Clinical and Laboratory Standards Institute; CLSI, "Performance Standards for Antimicrobial Susceptibility Testing", 20 ${ }^{\text {th }}$ Informational Supplement, CLSI document (2018).

20- R. El Fertas-Aissani, Y. Messai, S. Alouache and R. Bakour, "Virulence profiles and antibiotic susceptibility patterns of Klebsiella pneumoniae strains isolated from different clinical specimens", Pathologie Biologie, 61 (5), 209-16 (2013).

21- K. Mamlouk, I. B-B. Boubaker, V. Gautier, S. Vimont, B. Picard, S. B. Redjeb, et al., "Emergence and outbreaks of CTX-M $\quad \beta$-lactamase-producing Escherichia coli and Klebsiella pneumoniae strains in a Tunisian hospital", Journal of Clinical Microbiology, 44 (11), 4049-56 (2006).

22- S. Schubert, S. Cuenca, D. Fischer and J. Heesemann, "High-pathogenicity island of Yersinia pestis in Enterobacteriaceae isolated from blood cultures and urine samples: Prevalence and functional expression", The Journal of Infectious Diseases, 182 (4), 1268-71 (2000).

23- C. Schroll, K. B. Barken, K. A. Krogfelt and C. Struve, "Role of type 1 and type 3 fimbriae in Klebsiella pneumoniae biofilm formation", BMC Microbiology, 10 (1), 179 (2010).

24- T. May and S. Okabe, "Enterobactin is required for biofilm development in reduced-genome Escherichia coli", Environmental Microbiology, 13 (12), 3149-62 (2011).

25- V. L. Koga, G. Tomazetto, P. S. Cyoia, M. S. Neves, M. C. Vidotto, G. Nakazato, et al. "Molecular screening of virulence genes in extraintestinal pathogenic Escherichia coli isolated from human blood culture in Brazil", BioMed Research International, 2014, Article ID 465054, 1-9 (2014).

26- A. Paauw, M. A. Leverstein-van Hall, K. P. van Kessel, J. Verhoef and A. C. Fluit, "Yersiniabactin reduces the respiratory oxidative stress response of innate immune cells", PLoS ONE, 2009, 29, 4 (12), e8240 (2009). 
27- S. Bach, A. de Almeida and E. Carniel, "The Yersinia high-pathogenicity island is present in different members of the family Enterobacteriaceae", FEMS Microbiology Letters, 183 (2), 289-94 (2000).

28- L. C. Ristow and R. A. Welch, "Hemolysin of uropathogenic Escherichia coli: a cloak or a dagger?", Biochimica et Biophysica Acta (BBA)-Biomembranes, 1858 (3), 538-45 (2016).
29- P. Bennett, "Plasmid encoded antibiotic resistance: acquisition and transfer of antibiotic resistance genes in bacteria", British Journal of Pharmacology, 153 (S1), S347-S57 (2008). 


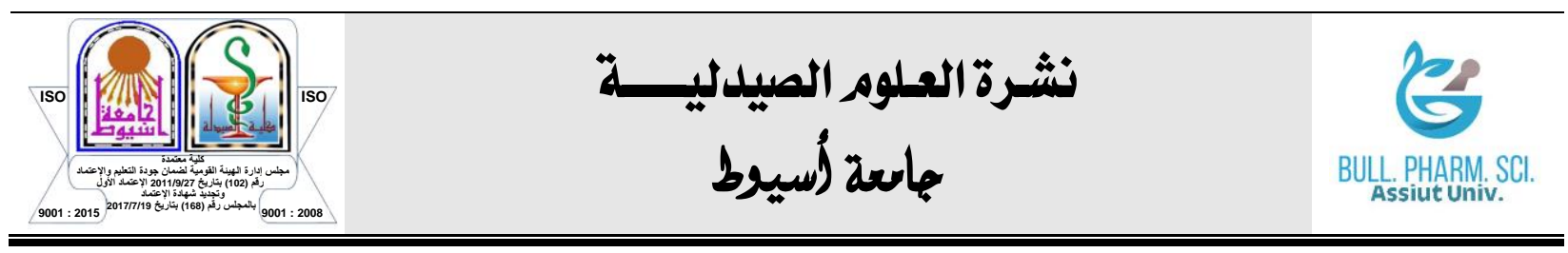

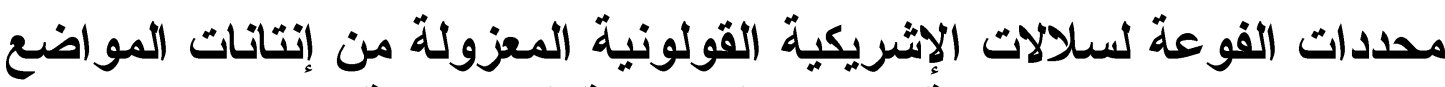

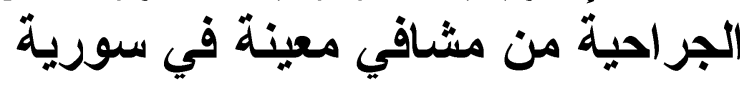

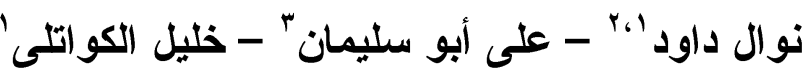

$$
\text { ' ' قسم الكيمياء الحيوية والأحياء الدقيقة ، كلية الصيدلة ، جامعة دمشق ، سوريا }
$$

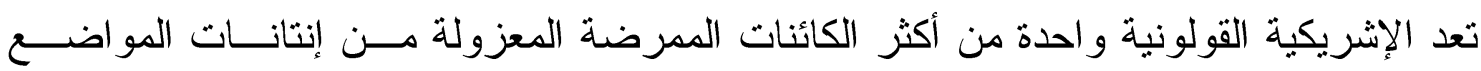

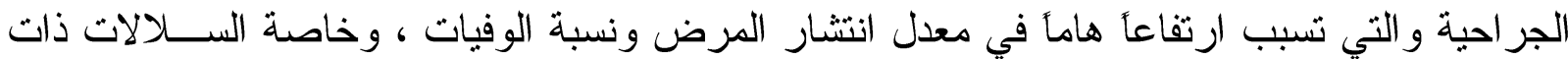

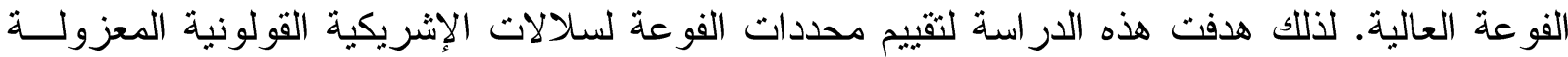

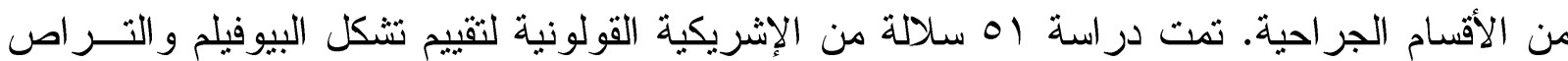

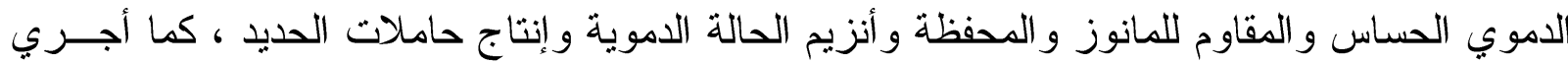

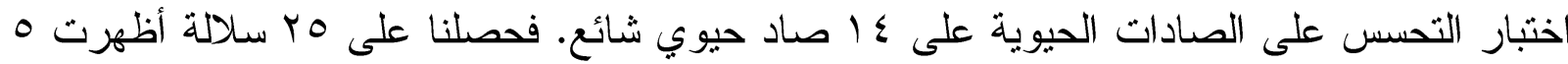
عو امل فوعة كما أبدت مقاومة متعددة لأكثر من 1 ( صاد حيوي ، ثم جرى استخلاص الدنا والبلازميد

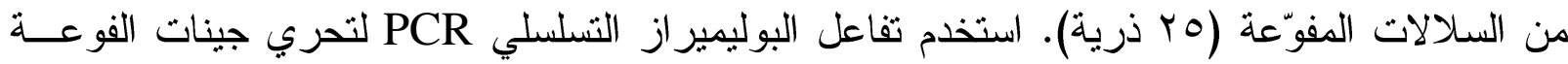
المحمولة على الدنا التي تشفر لعوامل الالتصاق (fimH-1, mrkD) و أنزيم الحالـــة الدمويــة (hlyA)

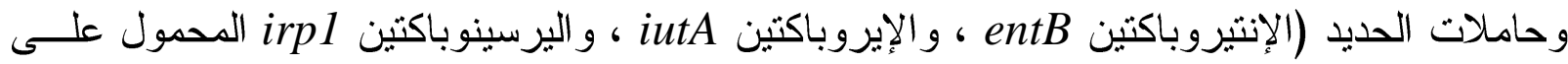
جزر القدرة الإمر اضية العالية HPI) ، كذلك جرى تحــري جينـات

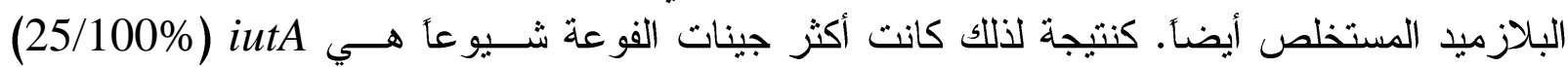

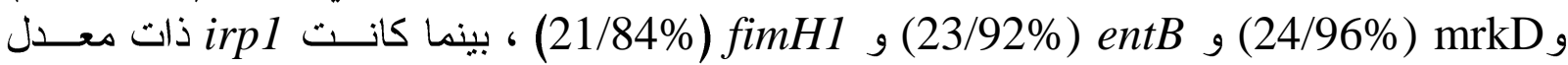

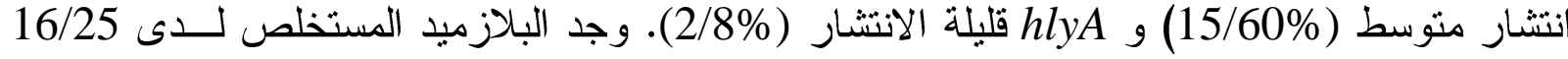

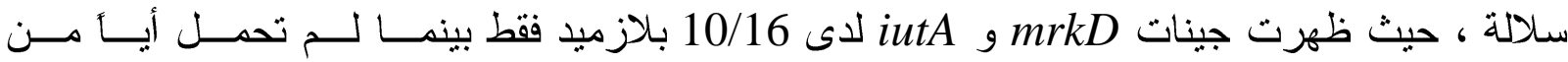

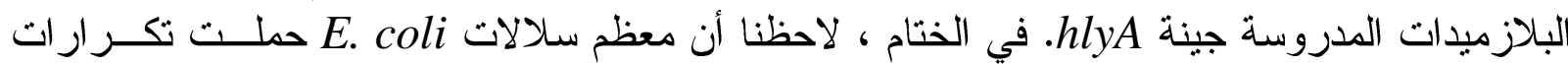

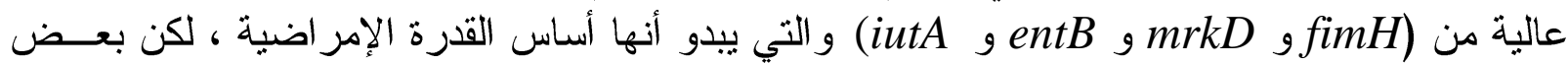

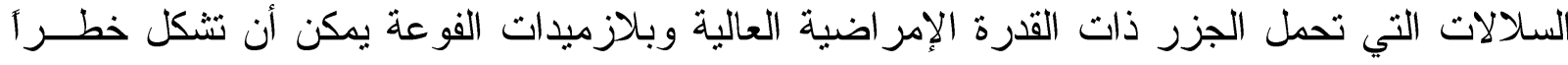
حقيقياً إذا انتشرت بين جر اثيم الإمعائيات الأخرى في الأقسام الجر احية. 